PLPB: Pendidikan Lingkungan dan Pembangunan Berkelanjutan

DOI: https://doi.org/10.21009/PLPB.171.02

DOI: 10.21009/PLPB

\title{
HUBUNGAN PENGETAHUAN TENTANG FEKUNDABILITAS DAN SIKAP HIDUP SEHAT DENGAN PERILAKU REPRODUKSI SEHAT
}

\author{
NING SETIANTI SMAN 5 DEPOK JAWA BARAT \\ DAN \\ NADIROH DOSEN FIS UNJ \\ setiantining@yahoo.com dan nadirohdr@yahoo.com
}

\begin{abstract}
The Objective of the research is to determine the relationship between the knowledge about fekundabilitas and healthy life style with healthy reproductive behavior in Depok.. The method which is used in this research is the correlation by survey research method. The technique of collected data using by test and non-tes with 80 respondents by multistage random sampling. The result of this research shows that the fekundabilitas knowledge and attitudes about healthy life style have a positive and significant relations with healthy reproductive behavior.
\end{abstract}

Keywords: fekundabilitas knowledge, healthy life style, healthy reproductive behavior.

\begin{tabular}{|l|l|l|l|}
\hline Volume XVII & Nomor 01 & Maret 2016 & ISSN 1411-1829 \\
\hline
\end{tabular}




\section{Pendahuluan}

Pengembangan program kependudukan diarahkan untuk lebih memperhatikan hak-hak reproduksi wanita yang dikenal dengan konsep kesehatan reproduksi. Reproduksi adalah proses melahirkan keturunan. Reproduksi sehat berarti proses melahirkan anak secara sehat dalam arti kelahiran anak terjamin kesehatannya sehingga harapan hidup anak makin tinggi.

\section{Badan Kesehatan Dunia (WHO)} menjelaskan bahwa konsep kesehatan reproduksi menyangkut proses, fungsi, dan sistem reproduksi pada seluruh tahap kehidupan, oleh karena itu dalam konsep kesehatan reproduksi terkandung asumsi bahwa setiap individu dapat memperoleh kehidupan seks yang bertanggung jawab, memuaskan, aman dan juga dapat mempunyai kapasitas bereproduksi. Dalam konsep ini dimaksudkan bahwa setiap pasangan dan individu mempunyai hak untuk menentukan jumlah, jarak antar kelahiran anak dan kapan mendapatkan anak. Agar supaya mereka dapat menggunakan hak-hak ini mereka memerlukan informasi, alat perlengkapan dan sarana lain.

Bahwa kesehatan reproduksi yang menekankan pada kesehatan wanita, hak-hak reproduksi dan kesehatan seksual, layak mendapat perhatian lebih serius, karena hak reproduksi merupakan bagian dari hak azasi manusia yang selama ini masih banyak diabaikan.
Keadaan yang ada di lapangan, tentu perilaku wanita pasangan usia subur dalam menjalankan reproduksinya secara sehat masih bervariasi, sebagai akibat perbedaan faktor-faktor yang terkait dengan kehidupan mereka, baik faktor ekternal (lingkungan) maupun internal (karakteristik individu; meliputi: pengetahuan, persepsi, sikap, intensi, dan kepribadian).

Menurut Skiner (1938) dalam Notoatmodjo (2010), merumuskan bahwa perilaku merupakan respons atau reaksi seseorang terhadap stimulus (rangsangan dari luar). Dengan demikian perilaku manusia terjadi melalui proses: Stimulus

Organisme $\square$ Respons, sehingga teori Skiner ini disebut teori "S-O-R" (stimulus-organismerespons).Hal ini berarti bahwa perilaku itu terbentuk di dalam diri seseorang dari dua faktor utama yakni: stimulus yang merupakan faktor dari luar diri seseorang tersebut (faktor eksternal) seperti faktor sosial budaya, dan respons yang merupakan faktor dari dalam diri orang yang bersangkutan (faktor internal) seperti pengetahuan dan sikap.

Di bidang kesehatan, terdapat teori atau model untuk meramalkan perilaku seseorang, diantaranya yaitu Theory of reasoned action atau behavioral intention theory yang dikembangkan oleh Fesbein dan Ajzen (1980) mencoba menjelaskan perilaku manusia utamanya yang berkaitan dengan permasalahan sosial psikologis. Teori ini menghubungkan keyakinan (believe),

\begin{tabular}{|l|l|l|l|}
\hline Volume XVII & Nomor 01 & Maret 2016 & ISSN 1411-1829 \\
\hline
\end{tabular}


sikap (attitude), kehendak (intention), dan perilaku.

Selanjutnya teori lain dikemukakan oleh Lawrence Green (1991) yaitu teori "PrecedProceed yang menganalisis perilaku manusia dari tingkat kesehatan. Menurut Green, kesehatan seseorang atau masyarakat dipengaruhi oleh 2 faktor pokok, yakni faktor perilaku (behavior causes) dan faktor di luar perilaku (non-behavior causes).

Kemudian teori "Behavior Intention" yang dikembangkan oleh Snehendu Kar (1980) berdasarkan analisisnya terhadap niatan orang bertindak atau berperilaku. Kar mencoba menganalisis perilaku kesehatan dengan bertitiktolak bahwa perilaku itu merupakan fungsi dari: (a) Niat seseorang untuk bertindak sehubungan dengan kesehatan atau perawatan kesehatannya (behaviour intention); (b) Dukungan sosial dari masyarakat sekitarnya (social-support); (c) Ada atau tidak adanya informasi tentang kesehatan atau fasilitas kesehatan (accessebility of information); (d) Otonomi pribadi yang bersangkutan dalam hal ini mengambil tindakan atau keputusan (personal autonomy); dan (e) Situasi yang memungkinkan untuk bertindak atau tidak bertindak (action situation).

Selanjutnya teori "Thoughts and Feeling" dikemukakan oleh Tim Kerja dari Organisasi Kesehatan Dunia atau WHO (1984) menganalisis bahwa yang menyebabkan seseorang itu berperilaku tertentu adalah karena adanya 4 alasan
pokok.Pemikiran dan perasaan (thoughts and feeling), yakni dalam bentuk pengetahuan, persepsi, sikap, kepercayaan-kepercayaan, dan penilaian-penilaian seseorang terhadap objek (dalam hal ini adalah objek kesehatan).

Berdasarkan kajian teoretik diatas maka dapat disintesakan bahwa perilaku reproduksi sehat adalah suatu tindakan yang terkait dengan kesehatan seperti pencegahan penyakit, cara peningkatan kesehatan dan cara memperoleh pengobatan yang tepat mengenai reproduksi sehat yaitu: 1) sehat fisik sistem reproduksi, fungsi dan prosesnya; 2) sehat mental sistem reproduksi, fungsi dan prosesnya; 3) sehat sosial sistem reproduksi, fungsi dan prosesnya; 4) terbebas dari penyakit terhadap sistem reproduksi, fungsi dan prosesnya; 5) terbebas dari kecacatan terhadap sistem reproduksi, fungsi dan prosesnya.

Pengetahuan adalah keseluruhan pemikiran, gagasan, ide, konsep dan pemahaman yang dimiliki manusia tentang dunia dan segala isinya termasuk manusia dan kehidupan.Dengan demikian pengetahuan mencakup penalaran, penjelasan dan pemahaman manusia tentang segala sesuatu, sekaligus mencakup kemampuan teknis manusia dalam memecahkan berbagai persoalan hidup yang dilakukan secara sistematis dan metodis.

Menurut Bloom terkait dengan suatu proses belajar maka, selalu melibatkan domain kognitif, domain apektif dan domain psikomotorik. Anderson and Krathwolh dalam

\begin{tabular}{|l|l|l|l|}
\hline Volume XVII & Nomor 01 & Maret 2016 & ISSN 1411-1829 \\
\hline
\end{tabular}


melakukan revisi terhadap taxonomy Bloom menyatakan bahwa dimensi proses kognitif mempunyai enam tingkatan, keenam tingkatan tersebut adalah (a) ingatan (remember), (b) pemahaman (understand), (c) penerapan (apply), (d) analisis (analyze), (e) evaluasi (evaluate) dan (f) kreatif (create). Menurut Eny Kusmiran, fekundabilitas (fecundability) adalah peluang untuk hamil dalam rentang siklus menstruasi, tanpa menggunakan alat kontrasepsi, dan melakukan aktivitas seksual. Fekundabilitas terbagi dua, yaitu effective fecundability dan appearent fecundability. Effective fecundability adalah peluang untuk mempertahankan kehamilan dalam kondisi janin hidup. Appearent fecundability adalah peluang untuk mampu melakukan konsepsi klinis. Dalam hal ini bahwa istilah fekundabilitas dapat diartikan sebagai potensi seorang wanita untuk menjadi hamil yang berbeda arti dengan fertilitas yaitu kemampuan seorang wanita untuk menghasilkan kelahiran hidup, karena fekundabilitas berkaitan dengan potensi untuk melahirkan, tanpa memperhatikan apakah seorang wanita benar-benar melahirkan seorang anak atau tidak.

Selanjutnya dapat disintesakan bahwa pengetahuan tentang fekundabilitas adalah segala sesuatu yang diketahui berdasarkan dimensi faktual, dimensi konseptual, dan dimensi prosedural dalam ruang lingkup fekundabilitas yang meliputi frekuensi dan waktu hubungan seksual, usia, laktasi, infeksi pada pelvis, nutrisi, aktivitas, obesitas, kontrasepsi oral, obat-obatan, faktor prenatal, gaya hidup dan paparan tempat kerja. Dimensi faktual meliputi (1) istilah; dimensi konseptual yang meliputi (1) klasifikasi dan (2) prinsip; dimensi prosedural meliputi (1) kebiasaan dan (2) metode.

Sikap secara umum dapat diartikan sebagai suatu kecenderungan (kesiapan).Soeitoe mengatakan, bahwa sikap merupakan suatu kecenderungan untuk bertingkah laku terhadap suatu objek.Kecenderungan yang dimaksud adalah suatu pola untuk mengadakan respon atau tanggapan yang dimiliki seseorang.

Respon yang timbul akan memberikan suatu kecenderungan untuk menerima atau menolak objek. Sebagaimana yang telah dikemukakan oleh Azwar, bahwa sikap sebagai respon evaluatif yang dapat berupa respon positif atau negatif.Dengan demikian respon positif akan menimbulkan kecenderungan untuk menerima objek, sedangkan respon negatif menimbulkan kecenderungan untuk menolak objek.

Kecenderungan untuk menerima atau menolak objek dipengaruhi oleh beberapa aspek, (komponen).Kamponen-komponen yang mempengaruhi sikap Menurut Mar 'at mencakup komponen kognisi, afeksi dan konasi. Komponen kognisi akan menjawab pertanyaan apa yang dipikirkan tentang objek, komponen afeksi akan menjawab pertanyaan tentang apa yang dirasakan terhadap objek, dan komponen konasi akan menjawab bagaimana kesediaan atau kesiapan untuk bertindak terhadap objek.Ketiga komponen

\begin{tabular}{|l|l|l|l|}
\hline Volume XVII & Nomor 01 & Maret 2016 & ISSN 1411-1829 \\
\hline
\end{tabular}


tersebut berinteraksi secara kompleks membentuk suatu sikap.

Sehat merupakan sebuah keadaan yang tidak hanya terbebas dari penyakit akan tetapi juga meliputi seluruh aspek kehidupan manusia yang meliputi aspek fisik, emosi, sosial dan spiritual. Menurut WHO sehat itu sendiri dapat diartikan bahwa suatu keadaan yang sempurna baik secara fisik, mental, dan sosial serta tidak hanya bebas dari penyakit atau kelemahan.

Menurut Hendrik L. Blum ada empat faktor yang mempengaruhi status kesehatan masyarakat yaitu: Lingkungan, Perilaku, Pelayanan Kesehatan dan Keturunan, selain berpengaruh langsung kepada kesehatan, juga saling berpengaruh satu sama lainnya. Status kesehatan akan tercapai optimal, bilamana keempat faktor tersebut bersama-sama mempunyai kondisi optimal juga.

Dengan demikian maka berdasarkan kajian teoretik di atas, dapat disintesakan bahwa yang dimaksud dengan sikap hidup sehat dalam penelitian ini adalah kecenderungan mental seseorang yang bersifat menetap terhadap orang, barang, atau objek tertentu pada dimensi kognisi, afeksi, dan konasi terhadap hidup sehat dalam aspek reproduksi sehat dengan indikator 1) memilih alat kontrasepsi yang aman, 2) kesadaran pada kesehatan reproduksi, 3) kecenderungan hidup sehat; dan aspek penyakit organ reproduksi dengan indikator 1) mengenal penyakit organ reproduksi, 2) kesadaran penyebab penyakit organ reproduksi, dan 3) keinginan mengatasi penyakit organ reproduksi.

Penelitian ini bertujuan untuk mendapatkan gambaran mengenai hal-hal yang mendasari perilaku reproduksi sehat yang dimiliki wanita pasangan usia subur yang selanjutnya disingkat menjadi PUS di Kelurahan Depok Jaya Kota Depok, yaitu mengetahui kekuatan hubungan antara: (1) pengetahuan tentang fekundabilitas dan perilaku reproduksi sehat, (2) sikap hidup sehat dan perilaku reproduksi sehat, dan (3) pengetahuan tentang fekundabilitas dan sikap hidup sehat dengan perilaku reproduksi sehat pada subyek wanita PUS yang berusia 21 49 tahun.

\section{Metodologi Penelitian}

Penelitian ini menggunakan metode penelitian survai.Penelitian dengan bentuk korelasional dimaksudkan untuk menunjukkan bentuk hubungan timbal balik antar variabel yang diteliti. Teknik ini juga untuk mengukur kadar hubungan antara variabel bebas yang diajukan $(\mathrm{X})$, dengan variabel terikat $(\mathrm{Y})$, baik secara sendiri-sendiri maupun bersama.

Pengumpulan data dilakukan melalui tiga instrumen yang berbentuk tes untuk variabel pengetahuan tentang fekundabilitas dan non tes yaitu berupa skala sikap untuk variabel sikap hidup sehat dan kuesioner untuk variabel perilaku reproduksi sehat yang dilaksanakan dengan cara responden merespon sendiri instrumen yang diberikan kepadanya.

\begin{tabular}{|l|l|l|l|}
\hline Volume XVII & Nomor 01 & Maret 2016 & ISSN 1411-1829 \\
\hline
\end{tabular}


Analisis data penelitian dilakukan dengan menggunakan statistik sebagai berikut; (1) deskripsi data yang meliputi rata-rata, rentangan, standar deviasi, median, modus, skewness, dan kurtosis, serta dilengkapi dengan distribusi frekuensi dan histogram, (2) pengujian persyaratan analisis yang meliputi pengujian homogenitas varians dan pengujian normalitas galat regresi, dan (3) pengujian hipotesis dilakukan dengan menggunakan regresi dan korelasi sederhana untuk masing-masing variabel bebas terhadap variabel terikat, dan regresi jamak untuk seluruh variabel bebas secara bersama-sama dengan variabel terikat, serta korelasi jamak dan korelasi parsial.

\section{Hasil Penelitian Dan Pembahasan}

Hasil analisis korelasional menunjukkan bahwa antara variabel baik secara sendiri-sendiri maupun secara bersama-sama, pengetahuan tentang fekundabilitas dan sikap hidup sehat memiliki hubungan positif dengan perilaku reproduksi sehat.

Hubungan positif tersebut memiliki arti bahwa pengetahuan tentang fekundabilitas dan sikap hidup sehat seiring dengan perilaku reproduksi sehat.Jadi peningkatan pengetahuan tentang fekundabilitas dan sikap hidup sehat diikuti dengan meningkatnya perilaku reproduksi sehat.Hubungan yang demikian berarti juga bahwa perilaku reproduksi sehat dapat ditelusuri, dijelaskan, atau bahkan diramalkan dari pengetahuan tentang fekundabilitas dan sikap hidup sehat.

Berdasarkan hasil pengujian hipotesis, ternyata ketiga hipotesis alternatif yang diajukan secara singnifikan dapat diterima. Uraian masingmasing penerimaan ketiga hipotesis yang dimaksud dapat dijelaskan sebagai berikut :

Pertama, pengujian hipotesis pertama menyimpulkan bahwa terdapat hubungan positif yang singnifikan antara pengetahuan tentang fekundabilitas dengan perilaku reproduksi sehat yang ditunjukkan oleh nilai $t_{\text {hitung }}$ sebesar 5,14 lebih besar dari $t_{\text {tabel}(0,05)(80)} 1,66$. Pola hubungan antara kedua variabel ini dinyatakan oleh persamaan regresi $\bar{Y}=87,482+0,834 \mathrm{X}_{1}$. Persamaan satu tingkat pengetahuan tentang fekundabilitas akan dapat mengakibatkan terjadinya perubahan pada perilaku reproduksi sehat sebesar 0,834 pada konstanta 87,482.

Hubungan antara Pengetahuan tentang Fekundabilitas $\left(\mathrm{X}_{1}\right)$ dengan Perilaku Reproduksi Sehat (Y) dengan menggunakan persamaan regresi $\bar{Y}=87,482+0,834 \mathrm{X}_{1}$, dapat dilihat pada grafik sebagai berikut yang diperoleh dari SPSS.

Perilaku Reproduksi Sehat

\begin{tabular}{|l|l|l|l|}
\hline Volume XVII & Nomor 01 & Maret 2016 & ISSN 1411-1829 \\
\hline
\end{tabular}


Tabel 1. Uji Keberartian Koefisien Korelasi Nihil

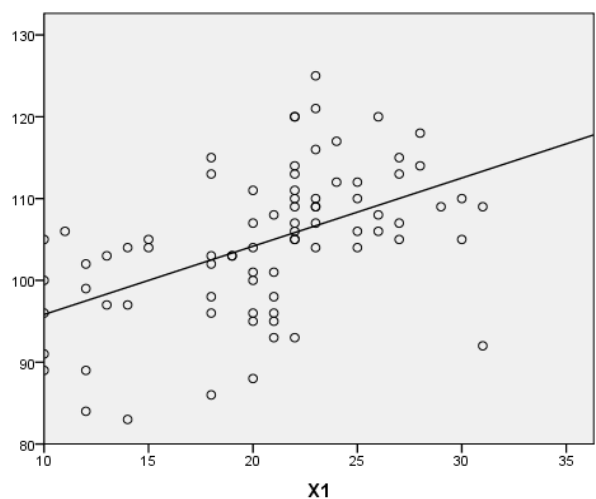

$\stackrel{\circ \text { Oobserved }}{\text { - inear }}$

Pengetahuan tentang Fekundabilitas

Gambar 1. Regresi Pengetahuan tentang Fekundabilitas dengan Perilaku Reproduksi Sehat

Hasil analisis korelasi sederhana antara pengetahuan tentang fekundabilitas dengan perilaku reproduksi sehat diperoleh nilai koefisien korelasi $r_{y 1}$ sebesar 0,503 Nilai ini memberikan pengertian bahwa keterkaitan antara pengetahuan tentang fekundabilitas dengan perilaku reproduksi sehat adalah singnifikan atau positif. Artinya, makin tinggi tingkat pengetahuan tentang fekundabilitas akan diikuti dengan naiknya perilaku reproduksi sehat tersebut.

Dengan menggunakan kriteria uji tolak $\mathrm{H}_{0}$ jika harga $t_{\text {hitung }}>t_{\text {tabel }}$ pada $\alpha=0,05$ dan $\mathrm{dk}=80$, maka koefisien korelasi signifikan. Hasil pengujian memberikan hasil sebagai berikut: $\left(\mathrm{r}_{\mathrm{y} 1}\right)$

\begin{tabular}{|c|c|c|l|}
\hline $\begin{array}{c}\text { Harga } \\
\text { Koef. }\end{array}$ & $\mathbf{t}_{\text {titun }}$ & $\mathbf{t}_{\text {tabel }}$ & \multicolumn{1}{|c|}{ Kesimpulan } \\
Korelasi & $\mathbf{g}$ & & \\
\hline $\mathrm{r}_{\mathrm{y} 1}=$ & 5,14 & 1,66 & Tolak $\mathrm{H}_{0}$ pada $\alpha=$ \\
0,503 & $*$ & & $\begin{array}{l}0,05 \quad \text { dengan } \\
\text { demikian korelasi } \\
\text { antara pengetahuan } \\
\text { tentang } \\
\text { fekundabilitas } \\
\text { dengan perilaku } \\
\text { reproduksi sehat } \\
\text { signifikan. }\end{array}$ \\
\hline
\end{tabular}

\section{Keterangan:}

Harga $\mathrm{t}_{\text {tabel }}$ adalah $\mathrm{t}_{(0,05)(80)}=1,66$

*koefisien korelasi signifikan

Besarnya sumbangan atau kontribusi variabel pengetahuan tentang fekundabilitas terhadap perilaku reproduksi sehat dapat diketahui dengan cara mengkuadratkan perolehan nilai koefisien korelasi sederhananya adalah sebesar 0,253 Secara statistik nilai ini memberikan pengertian bahwa kurang lebih 25,3\% variasi perilaku reproduksi sehat ditentukan atau dijelaskan oleh pengetahuan tentang fekundabilitas dengan pola hubungan fungsionalnya seperti ditunjukkan oleh persamaan regresi tersebut diatas.

Kedua, pengujian hipotesis kedua menyimpulkan bahwa terdapat hubungan positif yang singnifikan antara sikap hidup sehat dengan

\begin{tabular}{|l|l|l|l|}
\hline Volume XVII & Nomor 01 & Maret 2016 & ISSN 1411-1829 \\
\hline
\end{tabular}


perilaku reproduksi sehat yang ditunjukkan oleh nilai $t_{\text {hitung }}$ sebesar 3,74 lebih besar dari $t_{\text {tabel(}(0,05)(80)}$ 1,66. Pola hubungan antara kedua variabel ini dinyatakan oleh persamaan regresi $\bar{Y}=70,087+$ $0,339 X_{2}$. Persamaan satu tingkat sikap hidup sehat akan dapat mengakibatkan terjadinya perubahan pada perilaku repsoduksi sehat sebesar 0,339 pada konstanta 70,087.

Hubungan antara Sikap Hidup Sehat $\left(\mathrm{X}_{2}\right)$ dengan Perilaku Reproduksi Sehat (Y) dengan menggunakan persamaan regresi $\bar{Y}=70,087+$ $0,339 \mathrm{X}_{2}$, dapat dilihat pada grafik sebagai berikut yang diperoleh dari SPSS.

\section{Perilaku Reproduksi Sehat}

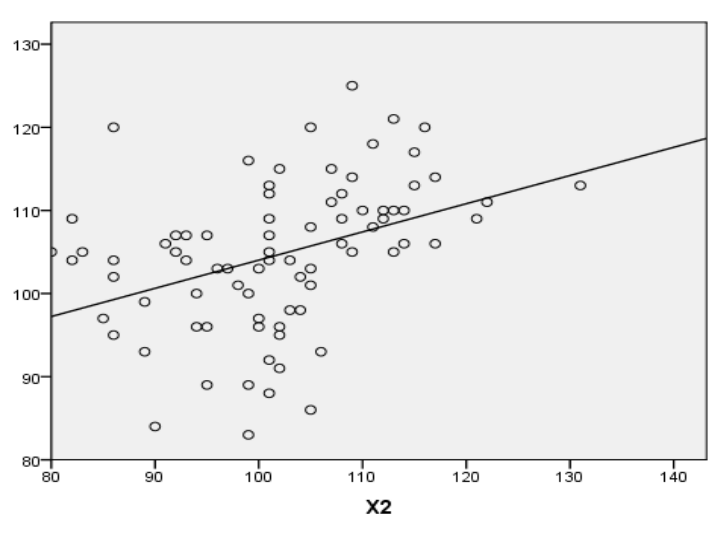

Sikap Hidup Sehat

Gambar 2. Regresi Sikap Hidup Sehat dengan Perilaku Reproduksi sehat

Hasil analisis korelasi sederhana antara sikap hidup sehat dengan perilaku reproduksi sehat diperoleh nilai koefisien korelasi $r_{\mathrm{y} 2}$ sebesar 0,390 Nilai ini memberikan pengertian bahwa keterkaitan antara sikap hidup sehat dengan perilaku reproduksi sehat adalah singnifikan atau positif. Artinya, makin tinggi tingkat sikap hidup sehat akan diikuti dengan naiknya perilaku reproduksi sehat tersebut.

Dengan menggunakan kriteria uji tolak $\mathrm{H}_{0}$ jika harga $t_{\text {hitung }}>t_{\text {tabel }}$ pada $\alpha=0,05$ dan $\mathrm{dk}=80$, maka koefisien korelasi signifikan. Hasil pengujian memberikan hasil sebagai berikut:

Tabel 2. Uji Keberartian Koefisien Korelasi Nihil $\left(r_{y 2}\right)$

\begin{tabular}{|c|c|c|c|}
\hline $\begin{array}{c}\text { Harga } \\
\text { Koef. } \\
\text { Korelasi }\end{array}$ & $\begin{array}{c}\mathbf{t}_{\text {hitun }} \\
\text { g }\end{array}$ & $\mathbf{t}_{\text {tabel }}$ & Kesimpulan \\
\hline $\begin{array}{c}r_{\mathrm{y} 2}= \\
0,390\end{array}$ & $\begin{array}{c}3,74 \\
*\end{array}$ & 1,66 & $\begin{array}{lr}\text { Tolak } \mathrm{H}_{0} \text { pada } \alpha=0,05 \\
\text { dengan } \\
\text { korelasi } \\
\text { pengetahuan } \\
\text { fekundabilitas } \\
\text { perilaku dentang } \\
\text { sehat signifikan. }\end{array}$ \\
\hline
\end{tabular}

\section{Keterangan:}

Harga $\mathrm{t}_{\text {tabel }}$ adalah $\mathrm{t}_{(0,05)(80)}=1,66$

*Koefisien korelasi signifikan

Besarnya sumbangan atau kontribusi variabel sikap hidup sehat terhadap perilaku reproduksi sehat dapat diketahui dengan cara mengkuadratkan perolehan nilai koefisien korelasi sederhananya adalah sebesar 0,1521 Secara statistik nilai ini memberikan pengertian bahwa kurang lebih $15,21 \%$ variasi perilaku reproduksi sehat ditentukan atau dijelaskan oleh sikap hidup sehat dengan pola hubungan fungsionalnya seperti

\begin{tabular}{|l|l|l|l|}
\hline Volume XVII & Nomor 01 & Maret 2016 & ISSN 1411-1829 \\
\hline
\end{tabular}


ditunjukkan oleh persamaan regresi tersebut diatas.

Ketiga, pengujian hipotesis ketiga menyimpulkan bahwa terdapat hubungan positif yang singnifikan antara pengetahuan tentang fekundabilitas dan sikap hidup sehat secara bersama-sama dengan perilaku reproduksi sehat yang ditunjukkan oleh nilai $F_{\text {hitung }}$ sebesar 15,6 Nilai ini jauh lebih besar dari pada nilai $F_{\text {tabel }}$ pada taraf singnifikan alpha 0,05 yaitu 3,12 , atau $F=$ $15,6>\mathrm{F}_{(0,01)(2: 77)}=3,12$ Pola hubungan antara ketiga variabel yang dinyatakan oleh persamaan regresi ganda $\overline{\mathrm{Y}}=72,108+0,682 \mathrm{X}_{1}+0,182 \mathrm{X}_{2}$. Persamaan ini memberikan informasi bahwa setiap perubahan satu unit skor pengetahuan tentang fekundabilitas dan sikap hidup sehat akan mengakibatkan terjadinya perubahan perilaku reproduksi sehat sebesar 0,682 atau 0,182.

Hasil analisis korelasi ganda antara pengetahuan tentang fekundabilitas dan sikap hidup sehat dengan perilaku reproduksi sehat diperoleh nilai koefisien korelasi ganda $\mathrm{R}_{\mathrm{y} 1.2}$ sebesar 0,537 Nilai ini menunjukkan bahwa keterkaitan antara pengetahuan tentang fekundabilitas dan sikap hidup sehat secara bersama-sama dengan perilaku reproduksi sehat baik. Dengan demikian, berarti makin naik pengetahuan tentang fekundabilitas dan sikap hidup sehat, maka diikuti dengan naik atau tingginya perilaku reproduksi sehat tersebut. Kriteria uji tolak $\mathrm{H}_{0}$ jika harga $\mathrm{F}_{\text {hitung }}>\mathrm{F}_{\text {tabel }}$ pada $\alpha$ $=0,05$, maka koefisien hasil pengujian sebagai berikut :
Tabel 3. Uji Keberartian Korelasi Jamak $\left(\mathrm{R}_{\mathrm{y} 1.2}\right)$

\begin{tabular}{|c|c|c|l|}
\hline $\begin{array}{c}\text { Harga } \\
\text { Koef. } \\
\text { Korelasi } \\
\left(\mathbf{R}_{\mathbf{y 1 . 2}}\right)\end{array}$ & $\mathbf{F}_{\text {hitung }}$ & $\mathbf{F}_{\text {tabel }}$ & \multicolumn{1}{|c|}{ Kesimpulan } \\
\hline 0,537 & $15,6^{*}$ & 3,12 & $\begin{array}{l}\text { Tolak } \mathrm{H}_{0} \text { pada } \alpha= \\
0,05 \text { dengan demikian } \\
\text { korelasi antara } \\
\text { pengetahuan tentang } \\
\text { fekundabilitas dengan } \\
\text { perilaku reproduksi } \\
\text { sehat signifikan. }\end{array}$ \\
\hline
\end{tabular}

Keterangan:

Harga $\mathrm{F}_{\text {tabel }}$ adalah $\mathrm{F}_{(0,05)(2: 77)}=3,12$ dan $\mathrm{F}_{(0,01)(2: 77)}$ $=4,89$

** Regresi sangat signifikan $\mathrm{F}_{\text {hitung }}>\mathrm{F}_{\text {tabel }}=$

Besarnya sumbangan atau kontribusi variabel pengetahuan tentang fekundabilitas dan sikap hidup sehat terhadap perilaku reproduksi sehat bersama-sama dapat diketahui melalui nilai koefisien determinasi $\left(\mathrm{R}_{\mathrm{y} 1.2}\right)^{2}$ sebesar 0,288. Hasil analisis tersebut menunjukkan bahwa lebih kurang $28,8 \%$ variasi perilaku reproduksi sehat ditentukan atau dijelaskan oleh pengetahuan tentang fekundabilitas dan sikap hidup sehat secara bersama-sama, seperti ditentukan oleh persamaan regresi tersebut diatas.

Untuk mengetahui kontribusi murni masing-masing variabel bebas terhadap variabel

\begin{tabular}{|l|l|l|l|}
\hline Volume XVII & Nomor 01 & Maret 2016 & ISSN 1411-1829 \\
\hline
\end{tabular}


terikat telah dilakukan analisis korelasi parsial. Kontribusi murni masing-masing variabel diketahui dengan melakukan pengontrolan variabel bebas lain. Hasil analisis tersebut dapat ditunjukkan peringkat hubungan sebagai berikut:

Tabel 4. Peringkat Kekuatan Hubungan antara Variabel Bebas dengan Variabel Terikat

\begin{tabular}{|c|c|c|}
\hline Korelasi & $\begin{array}{c}\text { Harga } \\
\text { Koefisien } \\
\text { Korelasi }\end{array}$ & Peringkat \\
\hline $\mathrm{r}_{\mathrm{y} 1.2}$ & 0,401 & Pertama \\
\hline $\mathrm{r}_{\mathrm{y} 2.1}$ & 0,217 & Kedua \\
\hline
\end{tabular}

Dari tabel di atas dapat dijelaskan sebagai berikut:

Pertama, kontribusi murni variabel bebas pengetahuan tentang fekundabilitas terhadap perilaku reproduksi sehat jika sikap hidup sehat dalam keadaan konstan, diperoleh nilai sebesar 0,401 . Kondisi ini menunjukkan bahwa terjadi penurunan kadar hubungan antara pengetahuan tentang fekundabilitas dengan perilaku reproduksi sehat.

Dengan demikian pengetahuan tentang fekundabilitas bukanlah satu-satunya variabel yang dapat menentukan perilaku reproduksi sehat, melainkan masih ada variabel yaitu sikap hidup sehat yang ikut berpengaruh.

Kedua, kontribusi murni variabel bebas sikap hidup sehat terhadap perilaku reproduksi sehat jika pengetahuan tentang fekundabilitas dalam keadaan konstan, diperoleh nilai sebesar
0,217 . Kondisi ini menunjukkan bahwa terjadi penurunan kadar hubungan antara sikap hidup sehat dengan perilaku reproduksi sehat, yang berarti bahwa sikap hidup sehat bukanlah satusatunya variabel yang dapat menentukan perilaku reproduksi sehat, melainkan masih ada variabel lain yaitu pengetahuan tentang fekundabilitas yang ikut berpengaruh.

Berdasarkan uraian tersebut diatas, maka dapat diketahui bahwa variabel bebas yang mempunyai hubungan yang paling kuat dan kontribusi yang paling besar terhadap variabel terikat adalah Pengetahuan tentang Fekundabilitas.

\section{Kesimpulan}

Hasil pengujian hipotesis menunjukkan ketiga hipotesis alternatif $\left(\mathrm{H}_{1}\right)$ yang diajukan dalam penelitian ini diterima dan menolak hipotesis nol $\left(\mathrm{H}_{0}\right)$. Kesimpulan penelitian dapat dirumuskan sebagai berikut :

Pertama, terdapat hubungan posistif antara pengetahuan tentang fekundabilitas dan perilaku reproduksi sehat.Ini berarti makin tinggi pengetahuan tentang fekundabilitas, maka semakin tinggi juga perilaku reproduksi sehat baik setelah dikontrol maupun tidak.

Kedua, terdapat hubungan positif antara sikap hidup sehat dengan perilaku reproduksi sehat.Ini berarti makin tinggi sikap hidup sehat, maka semakin tinggi juga perilaku reproduksi sehat baik setelah dikontrol maupun tidak.

\begin{tabular}{|l|l|l|l|}
\hline Volume XVII & Nomor 01 & Maret 2016 & ISSN 1411-1829 \\
\hline
\end{tabular}


Ketiga, terdapat hubungan positif antara pengetahuan tentang fekundabilitas dan sikap hidup sehat secara bersama-sama dengan perilaku reproduksi sehat.Ini berarti makin tinggi pengetahuan tentang fekundabilitas dan sikap hidup sehat, maka semakin tinggi juga perilaku reproduksi sehat.

\section{Daftar Pustaka}

Anderson, Lorin W. and David R Krothwohl. A Taxonomy for Learning Teaching and
Assesing, Abridged Edition. New York: Adison Wesley Logman, Inc., 2001. Azwar, Saiffudin. Sikap Manusia, Teori dan Pengukurannya. Yogyakarta: Liberty, 1988.

Kerap, Sonny dan Mikhael Dua.Ilmu Pengetahuan Sebuah Tinjauan Filosofi. Yogyakarta: Kanisius, 2001.

Kusmiran, Eny. Kesehatan Reproduksi Remaja dan Wanita. Jakarta: Salemba Medika, 2011.

Mar'at. Sikap Manusia, Perubahan serta Pengukurannya. Jakarta: Ghalia Indonesia, 1984.

Notoatmodjo, Soekidjo. Ilmu Perilaku Kesehatan. Jakarta: Rineka Cipta, 2010.

Notoatmodjo, Soekidjo. Kesehatan Masyarakat. Ilmu dan Seni. Jakarta: Rineka Cipta, 2007.

Soeito, Samuel. Psikologi Pendidikan (Jakarta: Lembaga Penerbit FEUI).

\begin{tabular}{|l|l|l|l|}
\hline Volume XVII & Nomor 01 & Maret 2016 & ISSN 1411-1829 \\
\hline
\end{tabular}


